\title{
KOMPONEN SEL JARINGAN IKAT
}

\author{
${ }^{1}$ Sunny Wangko \\ ${ }^{2}$ Ronny Karundeng
}

\author{
${ }^{1}$ Bagian Anatomi-Histologi Fakultas Kedokteran Universitas Sam Ratulangi Manado \\ ${ }^{2}$ Rumah Sakit Umum Gunung Maria Tomohon \\ Email: sunnywangko@yahoo.com
}

\begin{abstract}
Connective tissue is distributed in all parts of the body and its main function is to connect cells and tissues. Most of the embryonic connective tissues are derived from embryonal messenchymal tissues. There are a variety of connective tissues which are compatible with their functions and locations. The general difference of all connective tissues is the arrangement and composition of intercellular matrix. Connective tissues are composed of two major components: cells and intercellular matrices. Connective tissue cells, fixed cells or wandering cells, have their special functions which support each other to maintain the optimal histophysiology of the connective tissue.
\end{abstract}

Keywords: connective tissues, cells, histophysiology

\begin{abstract}
Abstrak: Jaringan ikat tersebar luas di seluruh bagian tubuh dengan fungsi utama untuk menghubungkan berbagai komponen sel atau jaringan. Hampir seluruh jaringan ikat embriologik berasal dari jaringan mesensimal embrional. Terdapat berbagai jenis jaringan ikat yang sesuai dengan fungsi dan lokasinya. Perbedaan utama dari berjenis-jenis jaringan ikat tersebut berdasarkan susunan dan komposisi matriks intersel. Jaringan ikat terdiri dari dua komponen dasar utama yaitu sel dan matriks intersel. Sel-sel jaringan ikat baik yang tetap maupun yang bebas mempunyai fungsi khusus masing-masing yang saling melengkapi untuk mempertahankan keutuhan histofisiologi jaringan ikat.
\end{abstract}

Kata kunci: jaringan ikat, sel, histofisiologi

Jaringan ikat tersebar luas di seluruh bagian tubuh dan berasal dari lapisan tengah embrio jaringan mesoderm, kecuali beberapa jenis jaringan ikat di daerah kepala yang berasal dari krista neural (ektoderm). Mesoderm ialah tempat di mana sel mesensim berasal. Sel ini mempunyai kemampuan untuk berkembang menjadi berbagai jenis sel atau jaringan tertentu (sifat pluripoten), seperti: jaringan otot yang dikhususkan untuk kontraksi.

Jaringan ikat terdiri dari dua komponen dasar utama yaitu: sel dan matriks intersel. Sel-sel jaringan ikat dapat dikelompokkan atas sel tetap dan sel bebas (transien) dengan fungsi khusus untuk masing-masing sel.
Susunan berbagai komponen matriks intersel jaringan ikat sedemikian bervariasi sehingga dikenal berbagai jenis jaringan ikat sesuai dengan fungsinya, antara lain:

- Merekatkan, mengikat atau menghubungkan berbagai sel atau bangunan yang ada di dalam tubuh.

- Sebagai media di mana tempat pembuluh darah lewat, untuk mendistribusikan berbagai bahan makanan pada organ yang bersangkutan dan mengangkut produk sisa hasil metabolisme.

- Pertahanan tubuh, sebagai tempat dimana proses imunologik berlangsung dan berfungsi sebagai sawar untuk mencegah penjalaran kuman. 
- Pemulihan jaringan.

Berbagai jenis jaringan seperti tulang rawan dan tulang, jaringan lemak, darah dan sumsum tulang juga merupakan jaringan ikat tetapi dengan fungsi khusus masing-masing. Tulang rawan dan tulang sebagai penyokong; jaringan lemak sebagai penyimpan tenaga/energi, serta darah dan sumsum tulang sebagai media transpor dan pertahanan sedangkan jaringan ikat yang dinamakan juga jaringan ikat sejati atau jaringan penyam-bung berfungsi untuk menghubungkan berbagai komponen sel dan jaringan.

\section{KOMPONEN DASAR UTAMA JARINGAN IKAT}

Terdapat dua komponen dasar utama dari jaringan ikat, yaitu sel dan matriks ekstrasel/intersel. Konponen sel terdiri dari sel tetap dan sel bebas. Yang termasuk komponen sel tetap ialah antara lain: sel mesenkim/perisit, fibroblas, sel lemak (adiposit), sel mast, dan makrofag; sedangkan yang termasuk komponen sel bebas ialah: sel plasma, limfosit, neutrofil, eosinofil, basofil, monosit, dan makrofag.

Matriks intersel/ekstrasel yaitu bahan yang terdapat di antara sel-sel pada jaringan ikat, dan terdiri dari protein serat (serat kolagen, serat retikular, dan sistem serat elastin) dan substansia dasar (ground substance) berupa glikosaminoglikan, proteoglikan, glikoprotein multiadhesif, dan cairan jaringan. Substansia dasar adalah bahan-bahan yang terdapat di antara sel-sel dan protein serat, sedangkan matriks ekstrasel adalah seluruh bahan yang terdapat di antara sel-sel, termasuk serat protein. Beberapa penulis menyebut-kan matriks ekstrasel sebagai substansia dasar saja.

\section{KOMPONEN SEL JARINGAN IKAT}

Komponen sel cari jaringan ikat terdiri dari sel tetap dan sel bebas (Gambar 1). Sel tetap (fixed cells) menetap di jaringan ikat karena sejak awal perkembangannya telah berada di jaringan tersebut dan umumnya mempunyai masa hidup yang cukup lama. Sel bebas (transien, wandering cells) berasal dari sumsum tulang kemudian masuk sirkulasi darah. Oleh rangsangan atau sinyal tertentu sel-sel ini akan meninggalkan sirkulasi darah dan bermigrasi ke jaringan ikat untuk menjalankan fungsi khusus dari masingmasing sel tersebut. Sebagian besar sel-sel bebas ini motil dan memiliki masa hidup pendek.

\section{Sel tetap}

Yang termasuk dalam komponen sel tetap ialah: sel mesenkim/perisit, fibroblas, sel lemak (adiposit), sel mast, dan makrofag; sedangkan yang termasuk komponen sel transien ialah: Sel plasma, limfosit, neutrofil, eosinofil, basofil, monosit, dan makrofag.

\section{Sel mesenkim/perisit}

Sel ini berbentuk bintang, lebih kecil dari fibroblas, biasanya terletak di sepanjang dinding kapiler, dan dikenal sebagai sel perivaskuler/sel adventisia, atau biasa juga dinamakan sel perisit. Sel perivaskuler dapat berdiferensiasi menjadi sel fibroblas, sel lemak dan sel otot polos (bersifat pluripoten) (Gambar 2A).

\section{Fibroblas}

Fibroblas tersebar luas seba-gai sel tetap pada berbagai jaringan ikat, berasal dari sel mesensim yang belum berdiferensiasi dan berfungsi memroduksi matriks ekstrasel jaringan ikat. Gambaran histologik fibroblas berupa sel besar berbentuk gepeng dengan sitoplasma bercabang langsing, atau berbentuk gelendong atau fusiformis. Inti lonjong atau memanjang dengan satu atau dua buah anak inti, batas sel tidak jelas, sitoplasma homogen bersifat basofil karena terdapat banyak retikulum endoplasma granular (menunjukkan aktifitas sintesis untuk menghasilkan matriks ekstrasel); beberapa penulis menggunakan istilah fibroblas 
aktif. Bila aktivitas sintesis fibroblas berkurang, maka struktur selnya akan berubah. Sitoplasma menjadi basofil lemah dan mengandung sedikit retikulum endoplasma granuler, tetapi ribosom bebas banyak, juga inti menjadi lebih padat dan gepeng; sel ini dinamakan fibrosit atau fibroblas inaktif. Kedua jenis sel ini dapat mengalami transisi, yaitu dari fibroblas menjadi fibrosit atau sebaliknya, sehingga beberapa penulis menggunakan istilah fibroblas saja (Gambar 2B). Fibroblas dikenal sebagai sel tetap pada jaringan ikat, tetapi sel ini masih dapat melakukan pergerakan pada jaringan ikat dan berperan pada regenerasi jaringan yang rusak akibat peradangan atau trauma (contoh: luka bedah) dengan membentuk jaringan parut.

Miofibroblas merupakan suatu variasi fibroblas dimana sitoplasmanya mengandung miofilamen yang dapat berkontraksi. Sel-sel ini terdapat pada permukaan luka dan berfungsi untuk menutup luka dengan cara berkontraksi.

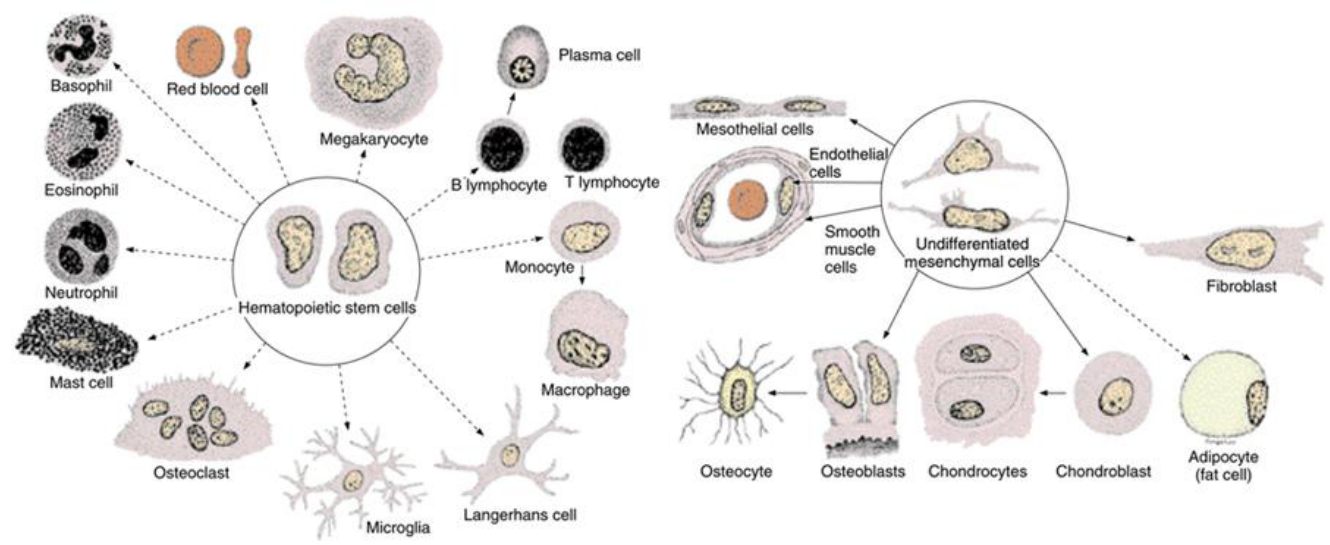

Gambar 1. Perkembangan jaringan mesenkim yang akan menjadi berbagai jenis jaringan ikat dalam tubuh manusia. Sumber: Junqueira LC, Carneiro J, 2005. ${ }^{5}$

\section{Sel lemak}

Sel lemak atau adiposit berasal dari sel mesensim. Dahulu diduga bahwa dalam keadaan tertentu sel fibroblas dapat berdiferensiasi menjadi sel lemak. Sel lemak telah mengalami diferensiasi akhir dan tidak dapat membelah lagi. Fungsi sel ini yaitu sintesis dan menyimpan trigliserida.

Secara histologik terdapat dua jenis sel lemak yaitu sel lemak unilokuler yang membentuk jaringan lemak putih, dan sel lemak multilokuler yang membentuk jaringan lemak coklat. Sel lemak unilokuler memiliki satu tetesan lemak yang besar dengan inti terdorong ke tepi dan sitoplasma tipis yang memberi gambaran seperti cincin cap (signet ring cell). Sel-sel lemak ini dapat berdiri sendiri atau dalam kelompok kecil; biasanya terdapat di sepanjang kapiler. Sel-sel lemak yang berkelompok besar dinamakan jaringan lemak. Sel lemak multilokuler memiliki banyak tetesan lemak dan inti biasanya tidak terdorong ke tepi. Dalam tubuh manusia lemak putih jauh lebih banyak dari lemak coklat (Gambar 2C).

Sel lemak unilokuler merupakan sel bulat besar dengan diameter dapat mencapai $120 \mu \mathrm{m}$. Di bawah mikroskop, pada jaringan lemak sel-sel lemak ini terlihat berbentuk polihedral. Dalam sitoplasmanya yang tipis terdapat kompleks Golgi jukstanuklear kecil, beberapa mitokondria berbentuk filamen, kadang terdapat sisterna dari rough endoplasmic reticulum (RER) dan sejumlah ribosom bebas. Pada sel lemak imatur, tetesan lemak masih berupa tetesan-tetesan lemak kecil yang belum berfusi dan dikelilingi 
oleh satu lapisan filamen intermedia vimentin berukuran sekitar $10 \mathrm{~nm}$ (Gambar 2C).

Sel lemak multilokuler bebeda dengan sel lemak unilokuler dimana selnya lebih kecil, berbentuk lebih poligonal dan lemak tersimpan dalam sejumlah vakuol-vakuol yang lebih kecil. Dalam sitoplasma terdapat banyak mitokondria tetapi sedikit polirobosom bebas. Jumlah RER sedikit, tetapi terdapat sejumlah smooth endoplasmic reticulum (SER).

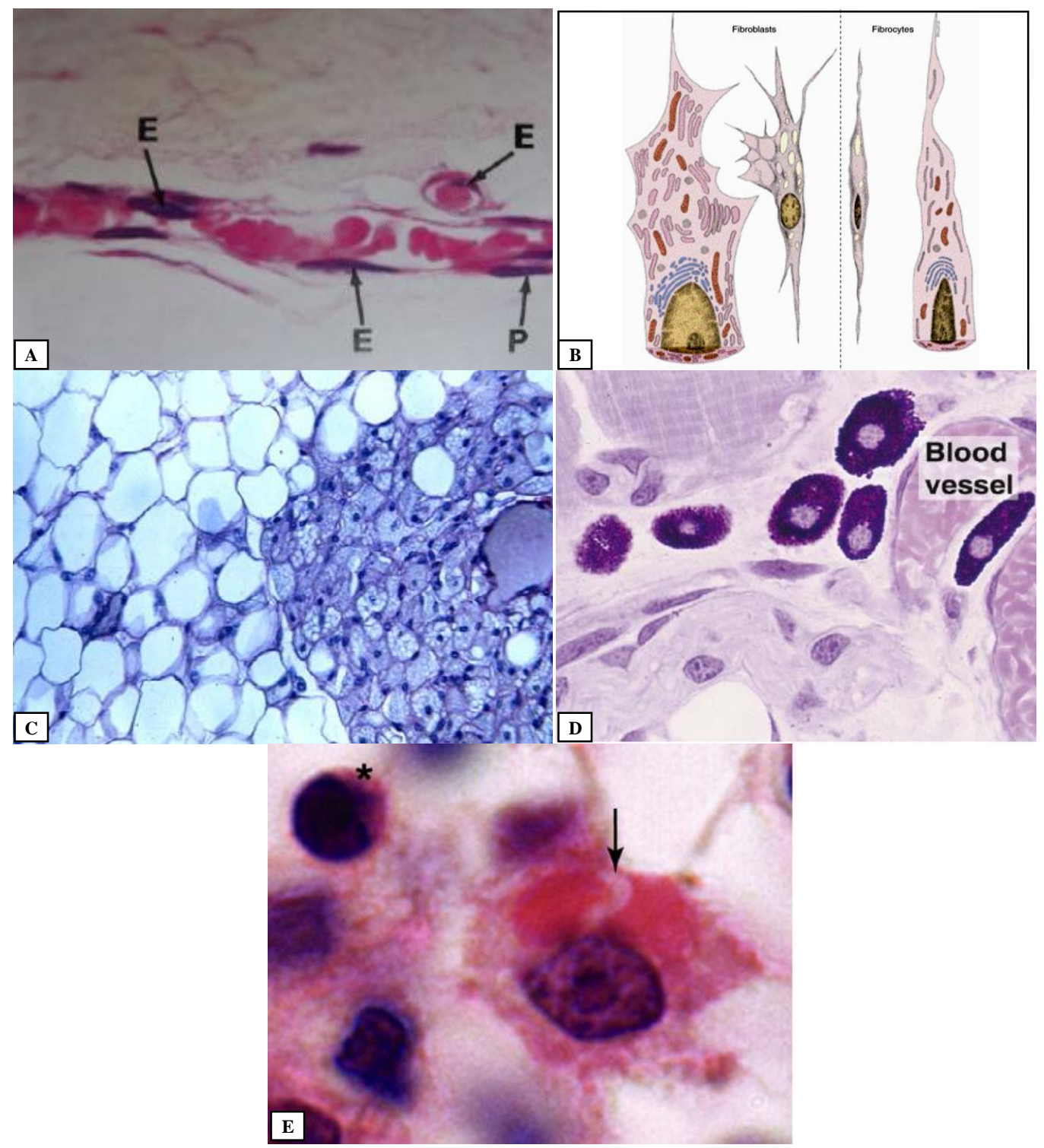

Gambar 2. Sel-sel tetap. A, Perisit; B, Fibroblas dan fibrosit; C, Adiposit; D, Sel mast; E, Makrofag. Sumber: Mescher AL, 2010. ${ }^{8}$

\section{Sel mast}

Sel mast merupakan salah satu sel besar pada jaringan ikat, berdiameter 20-30 $\mu \mathrm{m}$, berbentuk lonjong tidak teratur dengan pseudopodia pendek serta inti kecil (diameter 10-13 $\mu \mathrm{m})$ (Gambar 2D).
Sitoplasma penuh dengan granula berdiameter $\quad 0,3-2,0 \quad \mu \mathrm{m}$ yang mengandung heparin (atau kondroitin sulfat) yaitu sejenis glikosaminoglikan sulfat yang bersifat polianion; hal ini yang menyebabkan granula sel mast bersifat 
metakromasia. Selain itu, granula sel mast juga mengandung histamin (atau kondroitin sulfat), neutral protease (triptase, chymase, karboksilpeptidase), aryl sulfatase $(\gamma$ glukoronidase, kinino-genase, peroksidase dan superoksida dismutase), eosinophil chemotactic factor of anaphylaxis (ECF-A) dan neutrophil chemotactic factor (NCF). Bahan-bahan farmakologik di atas ini dinamakan mediator primer (preformed mediator).

Disamping substansia di atas, sel mast juga terlibat dalam sintesis sejumlah mediator derivat asam arahidonik dari membran sel; oleh karena itu sel mast juga menyintesis beberapa mediator lainnya seperti: leukotrin $\left(\mathrm{C}_{4}, \mathrm{D}_{4}, \mathrm{E}_{4}\right)$, tromboksan $\left(\mathrm{TXA}_{2}\right.$ dan $\left.\mathrm{TXB}_{2}\right)$ dan prostaglandin $\left(\mathrm{PGD}_{2}\right)$. Sel mast juga melepaskan beberapa sitokin lainnya yang bukan berasal dari asam arahidonik, yaitu antara lain platelet-activating factor $(P A F)$, bradikinin, interleukin (IL-4, IL-5, IL-6) dan tumor necrosis factor (TNF- $\alpha$ ); bahanbahan ini sering dimanakan mediator sekunder (newly synthesized).

Pelepasan bahan mediator dari granula sel mast akan menyebabkan reaksi alergi yang dinamakan reaksi hipersensitivitas segera (immediate hypersensitivity reaction), sebab reaksi yang terjadinya hanya selang beberapa saat setelah antigen masuk ke dalam tubuh, contoh syok anafilaktik.

\section{Sel bebas}

Sel-sel bebas umumnya merupakan sel-sel yang bermigrasi, masuk dari sistem sirkulasi. Umumnya sel-sel ini berasal dari sumsum tulang dan masuk ke jaringan melalui pembuluh venule pasca-kapiler.

\section{Makrofag}

Pada jaringan ikat yang tersebar di seluruh bagian tubuh manusia terdapat kelompok sel-sel yang dapat bergerak dan memiliki kapasitas fagositosis; sel-sel ini dinamakan makrofag atau histiosit. Dalam keadaan normal makrofag berfungsi secara terus menerus untuk memfagositosis berbagai bahan asing atau yang sudah tidak lagi diperlukan oleh tubuh, seperti sel-sel mati dan sisa sel, dengan cara menghancurkannya melalui sistem ensim lisosom yang terdapat dalam sitoplasma sel makrofag.

Secara histologik makrofag berbentuk tidak beraturan, berpenampang sekitar 10$30 \mu \mathrm{m}$, permukaan sel tidak rata ddan memiliki tonjolan-tonjolan seperti jari. Makrofag aktif mempunyai membran plasma yang berlipat-lipat; hal ini menunjukkan konsekuensi sifat sel yang dapat bergerak dan memfagositosis. Dalam sitoplasma yang basofil terdapat sejumlah vesikel kecil serta granula kecil dan padat. Inti berbentuk oval atau ginjal, terletak eksentrik, serta lebih kecil dan lebih gelap dibandingkan dengan fibroblas (Gambar 2E). Dengan mikrsokop elektron tampak kompleks Golgi yang berkembang baik, serta RER dan banyak lisosom yang pada mikroskop cahaya hanya terlihat sebagai granula padat dan kecil.

Sel makrofag berasal dari sel stem sumsum tulang yang masuk ke dalam sirkulasi sebagai monosit, kemudian ke jaringan ikat. Setelah diaktivasi oleh macrophage colony-stimulating factor (MCSF) sel tersebut menjadi matang sebagai makrofag, dengan masa hidup normal sekitar dua bulan.

Secara histologik makrofag digolongkan dalam dua jenis:

- Makrofag bebas: sel berbentuk tidak teratur, sitoplasma bertonjol-tonjol, inti berlekuk (sifat sel yang mobil) dengan kromatin yang lebih padat dari fibroblas.

- Makrofag tetap: inti sel berbentuk lonjong (sifat sel tidak mobil), dan selsel ini tersebar di sepanjang serat-serat yang terdapat di jaringan ikat.

Pada beberapa organ, makrofag diberi nama khusus, seperti: sel Kupffer (hati), sel mikroglia (sistem saraf pusat), sel Langerhans (kulit), sel septa (paru-paru) dan sel osteoklas (tulang), yang memiliki struktur dan fungsi yang berbeda. 


\section{Sel plasma}

Sel ini berasal dari limfosit B, dan memiliki sitoplasma yang lebih basofil dibandingkan dengan limfosit lainnya karena mengandung banyak retikulum endoplasma granuler yang menghasilkan imunoglobulin (Ig). Sel plasma mengandung sedikit mitokondria yang tersebar di antara RER dan kompleks Golgi dengan sepasang sentriol (dengan mikroskop cahaya struktur ini tampak sebagai daerah pucat/halo di dekat inti). Diameter sel ini sekitar $20 \mu$, dan inti sel letaknya agak ke tepi (eksentrik) dengan kromatin tersusun seperti roda pedati atau arloji (Gambar 3A). Masa hidup sel plasma dapat mencapai 10-20 hari.

Sel plasma akan menghasilkan antibodi dari rangsangan antigen yang bersangkutan, sehingga bila masuk antigen yang sama lebih dari satu kali akan terjadi reaksi antigen antibodi, menyebabkan efek dari antigen untuk dapat menimbulkan penyakit menjadi hilang atau lebih lemah.
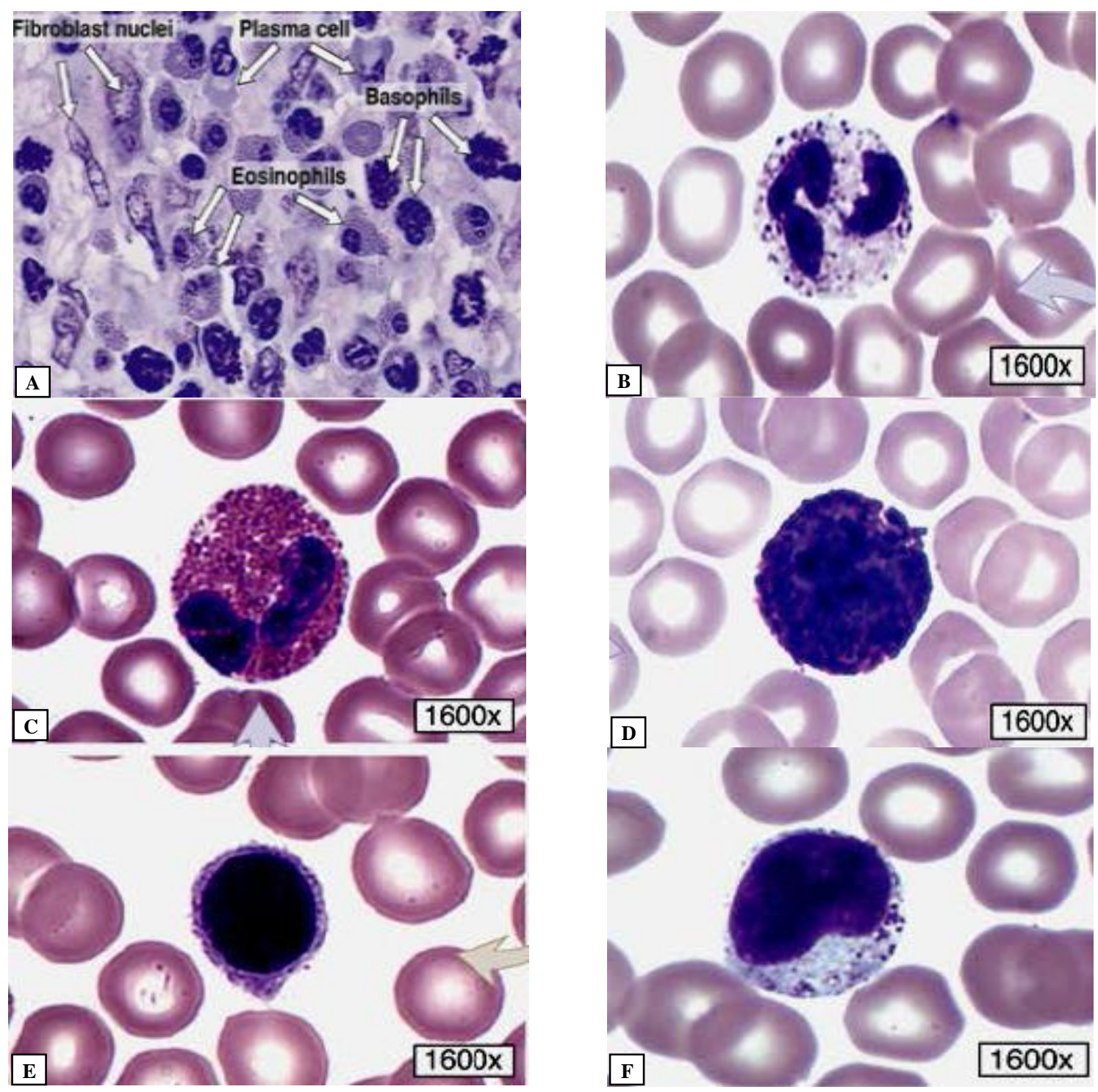

Gambar 3. Sel-sel bebas. A, Sel plasma; B, Neutrofil; C, Eosinofil; D, Basofil; E, Limfosit; F, Monosit. Sumber: Mescher AL, 2010. ${ }^{8}$ 


\section{Sel leukosit}

Pada keadaan tertentu, sel-sel leukosit yang beredar dalam pembuluh darah akan bermigrasi masuk ke jaringan ikat, terutama bila terjadi peradangan pada daerah tersebut. Sel-sel lekosit tersebut ialah:

- Neutrofil, dapat sangat meningkat pada peradangan umumnya, dan di jaringan ikat bila terjadi peradangan di tempat tersebut (Gambar 3B).

- Eosinofil, mirip lekosit lainnya yang tertarik datang ke daerah peradangan oleh leukocyte chemotactic factors. Mekanisme pertahanan sel ini terhadap parasit yaitu dengan melepaskan sitotoksin. Eosinofil juga akan datang pada daerah peradangan, dengan mengurangi reaksi alergik dan memfagostitosis kompleks antigen antibodi (Gambar 3C).

- Basofil, melepaskan beberapa bahan farmakologik untuk mengontrol proses peradangan (Gambar 3D).

- Limfosit, hanya terdapat dalam jumlah kecil dalam jaringan ikat; pada radang kronik limfosit biasanya akan meningkat (Gambar 3E).

- Monosit, dihasilkan dari sumsum tulang, kemudian beredar dalam sirkulasi dan masuk ke jaringan menjadi makrofag (Gambar 3F).

Jumlah sel-sel lekosit dalam jaringan akan meningkat sesuai dengan penyakit yang menyertai. Sebagai contoh: peningkatan jumlah sel eosinofil pada reaksi alergik; limfosit pada radang menahun umumnya; dan netrofil dapat sangat meningkat pada radang akut.

\section{SIMPULAN}

Jaringan ikat terdiri dari dua komponen dasar utama, yaitu sel dan matriks intersel. Komponen sel jaringan ikat terdiri dari selsel tetap dan sel-sel bebas. Masing-masing sel mempunyai fungsi khusus yang saling menunjang dan melengkapi untuk mempertahankan keutuhan jaringan ikatnya.

Telah dibawakan pada seminar "Connective tissue and musculoskeletal disorders" yang diselenggarakan oleh Perhimpunan Ahli Anatomi Indonesia Komisariat Manado tanggal 3 Oktober 2014 di Manado.

\section{DAFTAR PUSTAKA}

1. Fawcett DW. Connective Tissue. Bloom and Fawcett A Textbook of Histology. New York: Chapman \& Hall (Twelfth Edition), 1994; p. 133-67.

2. Fawcett DW, Jensh RP. Connective Tissue. Concise Histology (Second Edition). London: Arnold, 2002: p. 63-75.

3. Gartner P. Hiatt JL. Color Textbook of Histology (Third Edition). Philadelphia: Saunders Elsevier, 2007; p. 5263.

4. Geneser F. Jaringan ikat sejati. In: Tambajong $J$, alih bahasa. Atlas Berwarna Histologi. Jakarta: Binarupa Aksara, 2007; p. 27-35.

5. Junqueira LC, Carneiro J. Muscle Tissue. Basic Histology Text \& Atlas (Seventh Edition). New York: McGraw-Hill, 2005; 91-122.

6. Junquiera LC, Carneiro J, Kelley RO. Connective Tissue. In: Basic Histology (Seventh Edition). New Jersey: Prentice-Hall International Inc. a Lange Medical Book, 1992: p. 95-126.

7. Leeson CR, Leeson TS, Paparo AA. Jaringan ikat sejati. In: Tambajong $\mathrm{J}$, Wonodirekso S, penyunting. Buku Ajar Histologi (Edisi V). Jakarta: Penerbit Buku Kedokteran ECC, 1995: p. 10328.

8. Mescher AL. Junqueira's Basic Histology Text \& Atlas (Twelfth Edition). New York: Mc GrawHill, 2010.

9. Young B, Heath JW. Supporting/ connective tissue. In: Wheater's Functional Histology a text and colour atlas (Fourth Edition). New York: Churchill Livingstone, 2001: p. 65-80. 